\title{
用語解説
}

\section{携帯端末管理（Mobile Device Management）}

MDM と呼ばれる携帯端末機器の管理サービス名称である。従来は, 管理可能な携帯端末が専用機器として開発・実用されてい たが，MDMの登場で汎用性のある携帯端末で同等機能を実現できる管理が可能となった。例えば，特定のアプリケーションを入 れる，コンテンツを入れる，機能制限をかける，操作停止，デー夕削除など，詳細に端末を管理可能である。ネットワークヘの接 続が可能な端末であれば，遠隔操作にも対応している．

この機能の一部を利用して，学校や企業では, BYOD（Bring Your Own Device）の導入対応が柔軟に実現可能となった．組織で 利用する際には，利用者情報を埋め込む，一斉導入用アプリケーションライセンスを貸与する，ネットワーク接続認証情報を埋め 込むことも可能である。携带端末が想定外の状況で持ち出された際は，遠隔で端末の初期化と操作不能状態にする設定操作も実現 できる。これは端末へのセキュリティ対策向上にも貢献している，携帯端末の機能制限と合わせて利用した場合は，インストール されているアプリケーションなどの制御ができる。検証実験を行う際は，初期状態から同一の環境を短時間で構築可能である。携 帯端末の再利用時は，遠隔で短時間に初期状態に復元可能なため，再現実験の環境構築もさらに容易である。そうした技術的背景 には, AppConfig Community（https://www.appconfig.org）の存在が一役買っている。業界の開発者が集まり，Appセキュリテイや構 成フレームワークに基づき，標準化を提案している。コントロールセットが企業間で一貫化されることにより，ビジネスポリシー と要件に従って App の構成と管理が可能である。携带端末は, 一定の条件に沿う復元が可能で, 個々のセットアップ作業やユーザ 一の資格情報を都度必要とせずに，即座に利用できる。そうした携帯端末の応答状況は，管理情報として記録され，実験記録の補 助的証明としても利用可能である。

近年では，携帯端末以外の管理も対応できるようになったことから，EMM（Enterprise Mobility Management）という名称で呼ば れることもある

（桐蔭学園 情報基盤センター 山口大輔）

\section{lidar}

$\operatorname{radar}($ レーダー) が Radio Detection and Ranging のアクロニム（頭文字）からきていることになぞらえ, lidar（ライダ, ライダー） は Light Detection and Ranging から取られている。以前はLIDAR, LiDAR などのように大文字で表記されることが多かったが, radar や sonar と同じように, 近年は lidar も普及に伴い一般名称として小文字で表記されることが増えた. radarが可視光より低い周波数 の電波を用いて対象物からの反射波を計測する装置であるのに対して, lidar は可視光付近（紫外線や赤外線など）のより高い周波 数のレーザー光を用いて対象物からの反射波を測定する装置である。最も初期の lidar は，1点の距離を測るのみであったが，現在 はレーザー装置と反射波の受光器の角度を高速に変化させて広い角度の距離データを一度に出力できる lidar 装置が普及している。 これらは，3D レーザースキャナー（3D laser scanner）とも呼ばれる。 lidarの応用は，気象観測や，地表面のリモートセンシングに 加え, 小型化により近年は特にドローンや自動車の自動運転システムに積極的に利用されている。 lidarからの照射されるレーザー パルスは 1 点の距離しか測れないが, レーザー装置と受光器を物理的に回転させることで, 水平方向 360 度のスキャンが可能であ り，またレーザーを稼働する鏡に当て，鏡の角度を上下に変化させることで，垂直方向のスキャンを行うことも可能である，この ように lidarから得られた計測データは, 点群データ（point cloud）として３次元座標化され利用される． lidar はレーザー光を利用 しているため，特に目に対する安全性（eye-safe）が重要になる。自動運転車用 lidarに利用されるレーザーでは，905 nmの比較的 短い波長のレーザーは目の安全性のために出力を抑える必要があり,そのため $100 \mathrm{~m}$ を超える距離の検知が難しい. $1400 \mathrm{~nm}$ 以上の 光は網膜に到達しないため, $1550 \mathrm{~nm}$ 波長レーザーの方が出力を高めやすく, 観測距離を延ばすことが可能である。ただし，レー ザーのパルス長やスキャン速度によっても目への安全性は変化する。 lidarの小型化や低価格化が進むにつれ，スキャンのための回 転部品を無くしたソリッドステート式（solid state）が開発され，需要が高まっている．また，従来は 1 本のレーザー光を走査して スキャンするため画像全体の取り込みに時間がかかるのに対して, 一度に面として取り込む3D フラッシュライダー（flash imaging lidar）は，高速な移動体への検知に有利なため，注目が集まっている.

（東京情報大学 総合情報学部 マッキンケネスジェームス） 